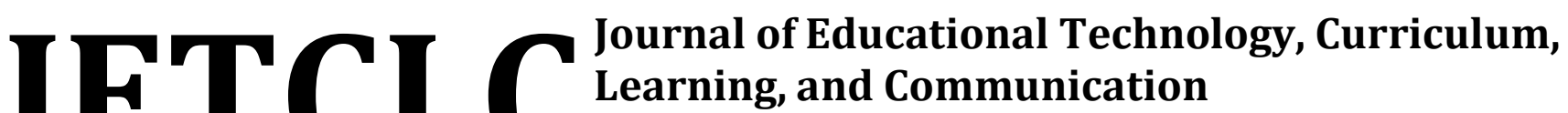 \\ Volume 1 Nomor 1 Januari 2021 Hal. 13-21 \\ ISSN: e-ISSN: $2774-8405$
}

\section{Pengaruh Workshop Media Pembelajaran Terhadap Peningkatan Kompeteni Guru Dalam Mengembangkan Media Pembelajaran.}

\author{
Muh. Afandy Gunawan Lahami \\ ${ }^{1}$ Muh. Afandy Gunawan Lahami/Teknologi Pendidikan \\ Universitas Negeri Makassar \\ Email: fandylahami012@gmail.com
}

C2021 - JETCLC. Ini adalah artikel dengan akses terbuka dibawah lisensi CC BY-NC-4.0

(https://creativecommons.org/licenses/by-nc/4.0/).

\begin{abstract}
The purpose of this research is to describe the implementation of instructional media workshops, describe the competence of teachers in developing presentation media, and find out whether there is an effect of instructional media workshops on increasing teacher competence in developing learning media at SMP Negeri 18 Makassar. The approach used is descriptive qualitative research, while the type of research used in this research is descriptive qualitative, referring to the correlation study (relationship). The data analysis used descriptive analysis and inferential statistical analysis. The results of this study indicate that the implementation of the instructional media workshop shows very effective results based on the observations of the instructor and training participants. The pretest and posttest results showed that there were significant differences. This also answers the hypothesis $H 1=$ There is an Effect of Learning Media Workshop on Increasing Teacher Competence in Developing Learning Media at SMP Negeri 18 Makassar.
\end{abstract}

Keywords: Education and training, Teacher, Learning Media,Teacher Competence

\begin{abstract}
ABSTRAK
Tujuan penelitian ini yaitu menggambarkan pelaksanaan workshop media pembelajaran, menggambarkan kompetensi guru dalam mengembangkan media presentasi, dan mengetahui apakah terdapat pengaruh workshop media pembelajaran terhadap peningkatan kompetensi guru dalam mengembangkan media pembelajaran di SMP Negeri 18 Makassar. Pendekatan yang digunakan yaitu penelitian kualitatif deskriptif sedangkan jenis penelitian yang digunakan dalam penelitian ini yaitu deskriptif kualitatif, mengacu pada studi korelasi (hubungan). Analisis data menggunakan analisis deskriptif dan analisis statistik inferensial. Hasil penelitian ini menunjukkan bahwa pelaksanaan workshop media pembelajaran menunjukkan hasil sangat efektif berdasarkan hasil observasi instruktur dan peserta pelatihan. Hasil pretest dan posttest menunjukkan terdapat perbedaan yang signifikan. Hal ini sekaligus menjawab hipotesis $H_{1}=A d a$ Pengaruh Workshop Media Pembelajaran Terhadap Peningkatan Kompetensi Guru Dalam Mengembangkan Media Pembelajaran Di SMP Negeri 18 Makassar.
\end{abstract}

Kata Kunci: Pendidikan dan Pelatihan, Guru, Media Pembelajaran, Kompetensi Guru

\section{PENDAHULUAN}

Pendidikan pada dasarmya tidak akan pernah dapat dipisahkan dari kehidupan masyarakat, melalui pendidikan yang baik akan dihasilkan sumber daya manusia yang terampil dan produktif sebagai subyek sekaligus obyek dalam mengisi pembangunan nasional. Upaya agar proses pendidikan dapat terlaksana sebagaimana diamanatkan oleh Undang-Undang Dasar 1945, maka diperlukan guru yang profesional.

Guru adalah sosok manusia yang harus digugu dan ditiru. Sebagai salah satu unsur dalam 
penyelenggaraan sistem pendidikan di sekolah, guru memegang peranan penting dalam penyelenggaraan pendidikan, di mana guru bersentuhan langsung dalam aktivitas belajar mengajar dan berinteraksi dengan anak dalam proses pembelajaran. Oleh karena itu, sangat diperlukan guru yang profesional.

Guru yang profesional adalah kunci untuk melaksanakan pendidikan yang berkualitas di sekolah. Kompetensi guru di Indonesia telah diatur dalam Peraturan Menteri Pendidikan dan Kebudayaan Nomor 16 Tahun 2007 tentang Standar Akademik dan Kompetensi Guru, yang menyatakan bahwa "standar kompetensi guru dikembangkan secara utuh dari empat kompetensi utama, yaitu kompetensi pedagogik, kepribadian, sosial, dan profesional." Kompetensi profesional guru yang diatur dalam Peraturan Menteri adalah menguasai materi, struktur, konsep, dan pola pikir keilmuan yang mendukung mata pelajaran yang diampu, menguasai standar kompetensi dan kompetensi dasar mata pelajaran atau bidang pengembangan yang diampu, mengembangkan materi pembelajaran yang diampu secara kreatif, mengembangkan keprofesionalan secara berkelanjutan dengan melakukan tindakan reflektif, memanfaatkan teknologi informasi dan komunikasi untuk berkomunikasi dan mengembangkan diri.

Adapun nilai Uji Kompetensi Guru (UKG) pada kegiatan karya inovatif berupa menemukan atau mengembangkan karya teknologi tepat guna yaitu dalam pembuatan media pembelajaran masih tergolong rendah. Berdasarkan data dari Kementrian Pendidikan dan Kebudayaan (2018) berupa hasil Uji Kompetensi Guru (UKG) untuk Kota Makassar Provinsi Sulawesi Selatan adapun nilai UKG untuk tingkat SMP yaitu 54,48. Dengan hasil yang demikian maka perlu dilaksanakan pelatihan untuk meningkatkan kompetensi professional guru. Adapun fasilitas yang dimiliki sekolah cukup memenuhi untuk pelaksanaan pelatihan media pembelajaran berupa listrik, digital light projector dan laptop.

Adapun penelitian sebelumnya yang menjadi acuan peneliti atau referensi peneliti dalam melakukan penelitian ini adalah penelitian yang dilakukan Murniati pada tahun 2016 yang berjudul Pengaruh Pendidikan dan Pelatihan Terhadap Kinerja Guru di SMK Negeri 1
Bungoro Kabupaten Pangkep, penelitian lainnya oleh Supri Yanto pada tahun 2019 yang berjudul Pengaruh Workshop Media Pembelajaran Terhadap Peningkatan Kompetensi Guru dalam Mengembangkan Media Pembelajaran Di SMP Negeri 26 Makassar.

Dari berbagai macam penelitian sebelumnya penelitian tersebut di atas ditemukan data bahwa pelaksanaan workshop atau pelatihan sangat mudah dilaksanakan oleh berbagai kalangan, bahkan di lingkungan guru sekalipun.

Berdasarkan uraian di atas maka penulis melakukan penelitian dengan judul "Pengaruh Workshop Media Pembelajaran Terhadap Peningkatan Kompetensi Guru dalam Mengembangkan Media Pembelajaran di SMP Negeri 18 Makassar".

Adapun tujuan penelitian ini yaitu (1) menggambarkan pelaksanaan workshop media pembelajaran, (2) menggambarkan kompetensi guru dalam mengembangkan media presentasi, (3) dan mengetahui apakah terdapat pengaruh workshop media pembelajaran terhadap peningkatan kompetensi guru dalam mengembangkan media pembelajaran di SMP Negeri 18 Makassar.

Hipotesis penelitian ini dapat dirumuskan sebagai berikut:

Ho: Tidak ada Pengaruh Workshop Media Pembelajaran Terhadap Peningkatan Kompetensi Guru dalam Mengembangkan Media Pembelajaran di SMP Negeri 18 Makassar.

H1: Ada Pengaruh Workshop Media Pembelajaran Terhadap Peningkatan Kompetensi Guru dalam Mengembangkan Media Pembelajaran di SMP Negeri 18 Makassar.

\section{METODE}

Pendekatan yang digunakan yaitu penelitian kualitatif deskriptif sedangkan jenis penelitian yang digunakan dalam penelitian ini yaitu deskriptif kualitatif, mengacu pada studi korelasi (hubungan).

Definisi operasional variabel dipakai untuk membantu permasalahan penelitian. Adapun 
variabel yang digunakan yaitu terdiri atas variabel bebas dan variabel terikat. Variabel bebas yaitu workshop media pembelajaran adalah kegiatan pelatihan media pembelajaran yang akan dilaksanakan di SMP Negeri 18 Makassar. Kegiatan pelatihan media pembelajaran berbasis aplikasi focusy berisi pengenalan user interface, pengenalan tools focusky, animasi menu dan lain-lain. Sedangkan variabel terikat yaitu peningkatan kompetensi guru dalam mengembangkan media pembelajaran adalah perubahan dari rendahnya kompetensi mengembangkan media presentasi menjadi mampu mengembangkan media berdasarkan tahapan pengembangan dan jenis media yang dilatihkan dalam penelitian ini.

Lokasi pelaksanaan penelitian ini di SMP Negeri 18 Makassar. Populasi penelitian ini ialah guru SMP Negeri 18 Makassar yang berjumlah 53 orang. Diantaranya 21 laki-laki dan 32 perempuan. Sampel pada penelitian ini berjumlah 18 orang. Diantaranya 7 laki-laki dan 11 perempuan.

Pengumpulan data dengan menggunakan observasi, tes, dan dokumentasi. Analisis data menggunakan analisis deskriptif dan analisis statistik inferensial.

\section{HASIL DAN PEMBAHASAN}

Hasil penelitian yang dilaksanakan di SMP Negeri 18 Makassar dengan membuat media pembelajaran menggunakan software focusky. Berdasarkan hasil observasi sebelumnya bahwa dari 18 guru yang menjadi sampel penelitian diketahui bahwa hanya beberapa guru yang pernah mengikuti kegiatan pelatihan penggunaan software focusky, jadi ada beberapa guru yang belum tahu dan tidak paham membuat media pembelajaran menggunakan software focusky dengan baik.

\section{Gambaran Pelaksanaan Workshop Media Pembelajaran}

Berdasarkan hasil observasi, pelaksanaan workshop ini dilaksanakan oleh SMP Negeri 18 Makassar dengan meliputi materi-materi baik teori maupun praktek. Pelaksaan workshop ini selama 2 hari.
Pada hari pertama pelaksanaan workshop diawali dengan pembukaan oleh MC kemudian memberikan kesempatan kepala sekolah memberikan sambutan-sambutannya. Kepala sekolah SMP Negeri 18 Makassar sangat senang dan mendukung kegiatan ini, menurut beliau kegiatan ini bisa membantu guru-guru dalam mengembangkan kemampuannya dalam menciptakan media pembelajaran yang bisa membuat siswa lebih antusias dan tidak bosan dalam proses pembelajaran. Kepala sekolah SMP Negeri 18 Makassar juga berharap jika kegiatan seperti ini bisa lagi di lakukan.

Selanjutnya MC mempersilahkan pemateri memaparkan mengenai biodata diri dan memperkenalkan diri. Setelah pemaparan tersebut pemateri memberikan soal pretest kepada peserta workshop yang berjumlah 18 orang untuk mengetahui pengetahuan awal peserta mengenai materi yang akan diberikan. Dari pengamatan observer masih banyak peserta yang keliatan kurang mengetahui mengenai materi tersebut.

Setelah pemberian soal pretest, peserta selanjutnya diajarkan mengenai tata cara penginstalan software focusky. Kegiatan ini dibantu oleh beberapa pendamping sehingga tidak memerlukan waktu yang lama. Selanjutnya pemateri memaparkan materi mengenai software focusky sambil mempraktekkan langkah-langkah yang harus dilakukan. Pada kegiatan ini pemateri juga melakukan tanya jawab kepada peserta. Sehingga ketika ada peserta yang belum memahami dan di jelaskan kembali.

Setelah peserta memahami, pemateri memberikan tugas dalam proses pemberian tugas pemateri dan pendamping memberikan bimbingan kepada peserta yang masih belum mengerti. Proses ada kegiatan ini yang menurut pengamatan observer sangat menunjukkan aura antusias dari para peserta. Peserta terlihat sangat tertarik mengenai software focusky, walaupun mash banyak peserta yang masih kaku dalam mengerjakan tugas.

Pada hari pertama dikerenakan antuias peserta yang begitu tinggi dalam melakukan Tanya jawab kepada pemateri waktu tidak terasa, 
sehingga kegiatan pemaparan presentasi media yang tealah dilakukan peserta tidak dapat dilakukan.

Pada hari kedua pemateri memaparkan materi kelanjutan mengenai software focusky tingkat antusias peserta dalam kegiatan ini lebih meninggat dari hari sebelumnya. Kemudian kegiatan selanjutnya yaitu mempersentasikan hasil meida yang telah di kembangkan oleh peserta yang telah dibuat pada hari sebelumnya. Dari pengamatan observer, hasil media yang telah dikembangkan peserta sudah sesuai langkah-langkah tetapi masih kurang inovatif. Pemateri selanjutnya melakukan tanya jawab kepada peserta mengenai materi focusky, setelah itu pemateri memeberikan tugas kembali kepada peserta. Dari pemberian tugas pada hari kedua ini observer melihat peserta telah mahir dalam menggunakan software focusky. Pematari dan pendamping lebih santai dalam membimbing para peserta.

Kegiatan selanjutnya adalah pemateri memberikan soal posttest untuk mengetahui kemampuan peserta setelah pemberian materi tersebut. Setelah pemberian soal posttest peserta antusias kembalikan dikarenakan kegiatan selanjutnya adalah presentasi hasil dari tugas mengembangkan media mereka. Banyak peserta yang tidak sungkan untuk mengajukan diri mempresentasikan hasil dari media yang telah dibuat. Dari pengamatan observer hasil media yang telah dibuat oleh beberapa peserta bagus bagi seorang pemula.

Akhir dari kegiatan ini adalah penyampaian kesan dan pesan antara peserta dan pemateri. Tidak ketinggalan sesi foto yang telah di nantikan oleh para peserta.

\section{Gambaran Kompetensi Guru dalam Mengembangkan Media Persentasi di SMP Negeri 18 Makassar}

Pada aktifitas kegiatan workshop, peserta pada hari pertama yang berjumlah 18 orang terlihat antusias mulai dari pengenalan, penyampaian tujuan pelatihan, penyampaian materi, tanya jawab tentang materi, melakukan praktek sesuai dengan langkahlangkah yang terdapat dalam media presentasi yang disajikan masih terlihat banyak peserta yang masih bigung dalam memahami fitur-fitur yang terdapat pada software focusky, proses pembimbingan selama proses praktek yang penuh dengan aura semangat dari peserta setiap penyampaian materi yang membuat pemateri dan pendamping kewalahan. Kegiatan refleksi bersama mengenai kegiatan workshop ini masih membuat peserta semangat. Hanya saja pada hari pertama kegiatan presentasi media yang telah dibuat oleh guru tidak dapat dilaksanakan dikarenakan kurangnya waktu.

Aktifitas kegiatan workshop pada hari kedua semakin terlihat antusias dari para peserta yang berjumlah 18 orang mulai dari pengenalan, penyampaian tujuan pelatihan, penyampaian materi, tanya jawab tentang materi, melakukan praktek sesuai dengan langkah-langkah yang terdapat dalam media presentasi yang disajikan disini peserta sudah paham mengenai fitur-fitur pda software focusky, proses pembimbingan selama proses praktek yang penuh dengan aura semangat dari peserta setiap penyampaian yang membuat pemateri serta pendamping sedikit mudah. Pada saat presentasi media yang telah dibuat peserta sangat semangat untuk menunjukkan hasil dari media yang telah mereka buat. Peserta sangat percaya diri menampilkan hasil presentasi yang telah dibuat. Sampai kegiatan refleksi bersama mengenai kegiatan workshop ini peserta masih ingin mendapatkan materi tambahan mengenai software focusky ini.

Secara umum, rekapulasi hasil observasi aktivitas peserta dapat dilihat melalui tabel berikut: 
Tabel 4.6 Rekapitulasi Hasil Observasi Aktifitas Peserta Pada Kegiatan Workshop

\begin{tabular}{|c|c|c|c|c|c|}
\hline \multirow{3}{*}{ No } & \multirow{3}{*}{ Aspek yang diamati } & \multicolumn{2}{|c|}{ Hari Pertama } & \multicolumn{2}{|c|}{ Hari Kedua } \\
\hline & & $\mathbf{Y a}$ & Tidak & Ya & Tidak \\
\hline & & 1 & $\mathbf{0}$ & 1 & $\mathbf{0}$ \\
\hline 1 & Kondisi objektif & 126 & 18 & 144 & 0 \\
\hline 2 & Skor maksimal & \multicolumn{2}{|c|}{144} & \multicolumn{2}{|c|}{144} \\
\hline 3 & Skor pencapaian & \multicolumn{2}{|c|}{126} & \multicolumn{2}{|c|}{144} \\
\hline 4 & Persentase Tingkat Pencapaian & \multicolumn{2}{|c|}{$87,50 \%$} & \multicolumn{2}{|c|}{$100 \%$} \\
\hline
\end{tabular}

Berdasarkan data tabel diatas dapat disimpulkan bahwa, dari aspek yang diamati berupa kondisi objektive pada hari pertama pelaksanaan workshop yaitu sebanyak 18 orang guru diperoleh hasil untuk pertanyaan 1-8 sebanyak 126 jawaban ya dan 18 orang jawaban tidak.

Hasil Hasil rerata persentase yang didapatkan dari akumulasi keselurahan pertanyaan sebesar $87.50 \%$ berada pada kualifikasi sangat efektif. Hari kedua kegiatan workshop juga dikategorikan sangat efektif, yang jauh lebih baik di bandingkan dihari pertama. Berdasarkan hasil observasi aktifitas peserta yaitu sebanyak 18 orang guru diperoleh hasil untuk pertanyaan 1-8 sebanyak 144 jawaban ya dan 0 orang jawaban tidak. Hasil rerata persentase yang didapatkan dari akumulasi keselurahan pertanyaan sebesar $100.00 \%$ berada pada kualifikasi sangat efektif.

\section{Analisis Statik Deskriptif}

Gambaran pemahaman peserta terhadap materi software focusky didapatkan melalui analisis statistik deskriptif. Penelitian ini dilaksanakan melalui kegiatan workshop media pembelajaran dengan dengan pemahaman guru sebelum dan sesudah mengikuti kegiatan workshop media pembelajaran dengan materi software focusky:

Tabel 4.7 Nilai Statistik Deskriptif Pretest dan Posttest

\begin{tabular}{|c|c|c|}
\hline \multirow{2}{*}{ Statistik } & \multicolumn{2}{|c|}{ Nilai Statistik } \\
\cline { 2 - 3 } & Posttest & Pretest \\
\hline Jumlah Sampel & 18 & 18 \\
\hline Nilai Terendah & 70 & 30 \\
\hline Nilai Tertinggi & 100 & 60 \\
\hline Nilai Rata-Rata & 87,222 & 46,111 \\
\hline Standar Deviasi & 3,79676 & 3,35935 \\
\hline
\end{tabular}

Berdasarkan data di atas, dapat dilihat bahwa pada posttest nilai terendah adalah 70 yang merupakan nilai minimum dan nilai tertinggi adalah 100 yang merupakan nilai maksimum dengan nilai rata-rata adalah 87,222 dan standar deviasi adalah 3,79676 sedangkan pada pretest nilai terendah adalah 30 yang merupakan nilai minimum dan nilai tertinggi adalah 60 yang merupakan nilai maksimum dengan nilai rata-rata adalah 46,111 dan standar deviasi adalah 3,35935. 


\section{Analisis Statik Inferensial}

Data yang diperoleh dari hasil penelitian berupa hasil tes (pretest dan posttest) akan diolah dengan menggunakan rumus statistik, setelah mendapatkan hasil dari data statistik selanjutnya diadakan pengujian hipotesis.
Data yang diperoleh berupa hasil test (pretest dan posttest) diolah menggunakan rumus statistika. Setelah memperoleh hasil dari analisis data statistik selanjutnya diadakan pengajuan hipotesis untuk memperoleh jawaban dari penelitian yang dilaksanakan.

Tabel 4.8 Analisis Data Nilai Posttest (x) dan Pretest (y)

\begin{tabular}{ccccccc}
\hline \multirow{2}{*}{ Skor } & \multirow{2}{*}{ Kategori } & \multirow{2}{*}{$\begin{array}{c}\text { Nilai } \\
\text { Huruf }\end{array}$} & \multicolumn{2}{c}{ Posttest } & \multicolumn{2}{c}{ Pretest } \\
\cline { 5 - 8 } & & & Frekwensi & Persentase & Frekwensi & Persentase \\
\hline $80-100$ & Baik Sekali & A & 17 & $94,44 \%$ & 0 & 0 \\
\hline $66-79$ & Baik & B & 1 & $5,56 \%$ & 0 & 0 \\
\hline $56-65$ & Cukup & C & 0 & 0 & 10 & 55,56 \\
\hline $46-55$ & Kurang & D & 0 & 0 & 0 & 0 \\
\hline $0-45$ & Gagal & E & 0 & 0 & 8 & 44,44 \\
\hline \multicolumn{2}{c}{ Jumlah } & & 18 & $100 \%$ & 18 & $100 \%$ \\
\hline
\end{tabular}

Berdasarkan pada tabel di atas maka dapat disimpulkan bahwa hasil posttest memiliki lebih banyak siswa yang berada pada kategori baik sekali sedangkan hasil pretest hanya beberapa siswa yang berada pada ketgori cukup. Sehingga peserta yang telah mengikuti workshop mendapatkan nilai yang lebih tinggi.

Tabel 4.9 Analisis Data Inferensial Posttest (x) dan Pretest (y)

\begin{tabular}{ccc}
\hline Analisis Data & X & Y \\
\hline Mean (M) & 87,222 & 46,111 \\
\hline Standar Deviasi Kuadrat & 64,545 & 57,109 \\
\hline Standar Deviasi Mean Kuadrat & 3,79676 & 3,35935 \\
\hline SDbm & 2,67509 & \\
\hline t-tes & 15,36808 & \\
\hline d.b & 34 \\
\end{tabular}

Berdasarkan hasil dari pengelolahan data diperoleh thitung sebesar 15.36808 sedangkan nilai $t_{\text {tabeldengan }} d b=34$ pada taraf signifikan diperoleh nilai table 1.69092. Karena nilai $t_{\text {hitung }}>t_{\text {tabel }}$ maka hipotesis nihil $\left(\mathrm{H}_{0}\right)$ yaitu "tidak ada pengaruh workshop media pembelajaran terhadap peningkatan kompetensi guru dalam mengembangkan media pembelajaran di SMP Negeri 18 Makassar" dinyatakan ditolak dan hipotesis kerja $\left(\mathrm{H}_{1}\right)$ yaitu: "ada pengaruh workshop media pembelajaran terhadap peningkatan kompetensi guru dalam mengembangkan media 
pembelajaran di SMP Negeri 18 Makassar" dinyatakan diterima.

\section{Pengaruh Workshop Media Pembelajaran}

Pengaruh workshop dapat dilihat dari observasi aktivitas peserta workshop juga dari hasil pretest dan posttest yang dilakukan oleh peneliti. Berdasarkan hasil aktivitas workshop dapat dilihat bahwa dihari pertama peserta workshop masih kaku dengan adanya software fokusky yang tergolong masih baru diketahui oleh guruguru, namun software ini memiliki daya tarik oleh peserta sebab dinilai menarik oleh peserta workshop sehingga memiliki motivasi untuk mengetahui dan mempelajari lebih intensif.

Berdasarkan hasil dari pengelolahan data

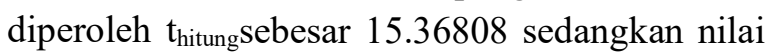
$t_{\text {tabeldengan }} \mathrm{db}=34$ pada taraf signifikan diperoleh nilai table 1.69092. Karena nilai $t_{\text {hitung }}>$ $\mathrm{t}_{\text {tabel }}$ maka hipotesis nihil $\left(\mathrm{H}_{0}\right)$ yaitu "tidak ada pengaruh workshop media pembelajaran terhadap peningkatan kompetensi guru dalam mengembangkan media pembelajaran di SMP Negeri 18 Makassar" dinyatakan ditolak dan hipotesis kerja $\left(\mathrm{H}_{1}\right)$ yaitu: "ada pengaruh workshop media pembelajaran terhadap peningkatan kompetensi guru dalam mengembangkan media pembelajaran di SMP Negeri 18 Makassar" dinyatakan diterima.

Secara keseluruhan pelaksanaan workshop di SMP Negeri 18 Makassar berjalan dengan sangat baik dalam rangka meningkatkan kompetensi guru. Workshop memberikan kesempatan kepada guru untuk mendapatkan pengetahuan dan keterampilan baru yang pada akhirnya akan meningkatkan prestasi belajar siswa.

\section{Pembahasan}

Penelitian ini dilaksanakan untuk menggambarkna kompetensi guru dalam mengembangkan media presentasi, implementasi workshop media pembelajaran terhadap peningkatan kompetensi guru dalam mengembangkan media pembelajaran. Penelitian ini hanya menggunakan satu kelas yaitu kelas esperimen tanpa menggunakan kelas pembanding. Jadi semua sampel mendapat materi software focusy menggunakan media presentasi berbasis multimedia interaktif.

Pada bagian ini, akan dibahas mengenai hasil penelitian yang dilaksanakan di SMP Negeri 18 Makassar pada guru sebagai peserta workshop dengan jumlah 18 orang sebagai responden penelitian maka diperoleh hasil penelitian melalui observasi aktivitas instruktur dan observasi aktivitas peserta. Observasi dilaksanakan dengan tujuan untuk memperoleh gambaran pelaksanaan penelitian secara keseluruhan mulai dari awal hingga akhir proses penelitian.

Berdasarkan hasil penelitian diperoleh nilai pretest dengan materi Software Focusky pada workshop pembuatan media pembelajaran terdapat 2 orang guru memperoleh nilai 60 dengan tingkat persentase sebasar $11,12 \%$ yang dikategorikan cukup, 8 orang guru memperoleh nilai 50 dengan tingkat persentase sebesar $44,44 \%$ yang dikategorikan kurang, 7 orang guru memperoleh nilai 40 serta 1 orang guru memperoleh nilai 30 dengan tingkat persentase $44,44 \%$ yang dikategorikan gagal dan tidak terdapat guru memperoleh nilai lebih 60 yang dikategorikan baik dan sangat baik.

Nilai posttest dengan materi Software Focusky pada workshop pembuatan media pembelajaran terdapat 7 orang guru memperoleh nilai 80,7 orang guru memperoleh nilai 90 serta 3 orang guru memperoleh nilai 100 dengan tingkat persentase $94,44 \%$ yang dikategorikan sangat baik, 1 orang guru memperoleh nilai 70 dengan tingkat persentase sebesar 5,56\% yang dikategorikan baik, dan tidak terdapat guru memperoleh nilai lebih rendah dari 70 yang dikategorikan cukup, kurang dan gagal, kemudian hasil tersebut dianalisis secara deskriptif dan inferensial.

Hasil analisis tersebut menunjukkan adanya pengaruh workshop media pembelajaran terhadap peningkatan kompetensi guru dalam mengembangkan media pembelajaran di SMP Negeri 18 Makassar.

Pemanfaatan media dalam kegiatan workshop 
media mampu meningkatkan semangat dan antusias peserta pelatihan dalam mempelajari software focusky. Selain meningkatkan semangat dan antusias peserta pelatihan, media pembelajaran yang digunakan juga memudahkan peserta pelatihan memahami materi software focusky karena media yang digunakan yaitu media presentasi berbasis multimedia interaktif yaitu media yang dapat mensimulasikan secara langsung penggunaan software focusky secara detail.

\section{SIMPULAN DAN SARAN}

\section{SIMPULAN}

Gambaran pelaksanaan workshop media pembelajaran menggunakan software focusky, subjek yang diobservasi adalah instruktur dan guru sebagai peserta pelatihan. Dari hasil observasi aktivitas instruktur dari kesembilan kategori yang digunakan hanya satu kategori yang tidak dilaksanakan pada hari pertama kegiatan yaitu presentasi media yang telah dikembangkan oleh perwakilan dikarenakan waktu kegiatan yang tidak cukup. Maka kegiatan tersebut tidak dilaksanakan dan dilakukan pada hari selanjutnya. Dari hasil observasi peserta yang menunjukkan peningkatan semangat, antusias serta peningkatan pemahaman peserta terhadap materi software focusky.

Peningkatan kompetensi guru di SMP Negeri 18 Makassar dapat dilihat berdasarkan hasil pretest dan posttest yang menunjukkan adanya perubahan nilai peserta workshop sebelum dan sesudah dilakukan kegiatan workshop.

\section{DAFTAR RUJUKAN}

Arikunto, Suharsimi. 2010. Presedur Penelitian Pendekatan Praktek. Yogyakarta: Rineka Cipta.

Arsyad, Azhar. 2013. Media Pembelajaran. Jakarta: RajaGrafindo Persada.

Daryanto. 2010. Media Pembelajaran. Yogyakarta: Gava Media.

Dewi, Tiara Anggia. 2015. "Pengaruh Profesionalisme Guru dan Motivasi Kerja Terhadap Kinerja Guru Ekonomi SMA Se-Kota Malang”. Skripsi. Pendidikan Ekonomi. Universitas Muhammadiyah Metro Malang. Malang
Hasil dari workshop media pembelajaran menggunakan media presentasi berbasis multimedia interaktif menjadi kesimpulan terjadinya peningkatan pemahaman gutu dan membenarkan hipotesis yakni "ada pengaruh workshop media pembelajaran terhadap peningkatan kompetensi guru dalam mengembangkan media pembelajaran di SMP Negeri 18 Makassar".

Berdasarkan hasil analisis data menunjukkan bahwa terdapat pengaruh positif dan signifikan antara kegiatan sebelum dan sesudah workshop di SMP Negeri 18 Makassar. Sehingga, hipotesis yang mengatakan bahwa "ada pengaruh workshop media pembelajaran terhadap peningkatan kompetensi guru dalam mengembangkan media pembelajaran di SMP Negeri 18 Makassar", dapat diterima.

\section{SARAN}

Adanaya pelaksanaan pelatihan selanjutnya untuk meningkatkan kompetensi guru. Guru diharapkan dapat menerapkan penggunaan media pembelajaran dalam proses pembelajaran.

Diharapkan adanya penelitian lanjutan mengenai pengaruh workshop media pembelajaran terhadap peningkatan kompetensi guru, dan lokasi penelitian lebih diperluas lagi menjadi beberapa sekolah sehingga hasil penelitian ini lebih baik.

Hadi, Sutrisno. 2015. Statistik. Yogyakarta: Pustaka Belajar

Hosnan, M. 2016. Etika Profesi Pendidik. Bogor: Ghalia Indonesia

Karim, Abdul. 2007. Media Pembelajaran. Makassar: Badan Penerbit UNM

Kemendikbud. 2018. Neraca Pendidikan Daerah, (Online) https://npd.kemdikbud.go.id/?appid=ukg (di akses pada tanggal 24.11.2009 jam 21.45)

Munir. 2013. Multimedia, Konsep, dan Aplikasi dalam Pendidikan (cetakan ke 2) Bandung: Alfabeta,CV 
Murniati. 2016. "Pengaruh Pendidikan dan Pelatihan Terhadap Kinerja Guru di SMK Negeri 1 Bongoro Kabuaten Pangkep". Skripsi. Pendidikan Administrasi Perkantoran. UNM. Makassar.

Noor, Juliansyah. 2014. Metodologi Penelitian. Jakarta: Prenadamedia Group

Popescu, George. 2014.Focusky-an Intuitive and Persatile Presentation Maker for Everyday use, (online); http://www.softpedia.com/reviews/mac/f ocusky-review-456010.shtml (di akses pada tanggal 24.11.2019 jam 21:10)

Priyanti, Endah Tri. 2010. Keterampilan Menggunakan Media Pembelajaran. Malang: UPT PPL UNM

Rudini. 2018. "Pengembangan Multimedia Pembelajaran Interaktif Menggunakan Software Focusky pada Mata Pelajaran Sosiologi Kelas XI SMA Negeri 2 Bantaeng". Skripsi. Teknologi Pendidikan. UNM. Makassar.

Rusman, 2014. Model-Model Pembelajaran. Jakarta: PT Raja Grafindo Persada

Rusman, dkk. 2013. Pembelajaran Berbasis Teknologi Informasi dan Komunikasi. Jakarta: Rajawali Pers.

Sadiman, dkk. 2012. Media Pendidikan. Jakarta: PT Raja Grafindo Persada.

Saragih, A. Hasan. 2008. "Kompetensi Minimal Seorang Guru dalam Mengajar". Tesis. Universitas Negeri Medan. Medan.

Setiawan, Ferry. 2018. "Pengaruh Penggunaan Aplikasi Focusky Berbasis Media Presentasi Terhadap Hasil Belajar Siswa Pada Mata Pelajaran Bahasa Indonesia Kelas VIII Di SMP Negeri 3 Belopa". Skripsi. Teknologi Pendidikan. UNM. Makassar.

Sudijono, Anas. 2013. Pengantar Evaluasi Pendidikan. Jakarta: PT RajaGrafindo Persada

Sudjana, Nana. 2013. Penilaian Hasil Belajar Mengajar. Bandung: PT Remaja Rosdakarta
Susilana R \& Riyana C. 2009. Media Pembelajaran. Bandung: Cv Wana Prima.

Undang - Undang Republik Indonesia Nomor 14 Tahun 2005 Tentang Guru dan Dosen. http://luk.staff.ugm.ac.id/atur/UU142005GuruDosen.pdf

Undang - Undang Republik Indonesia Nomor 20 Tahun 2003 Tentang Sistem Pendidikan Nasional. Jakarta: Sinar Grafika

Waryanto, N.H. 2008. Multimedia Interaktif dalam Pembelajaran. Makalah disampaikan pada kegiatan Diklat Guru SMK Muhammadiyah 3 Klaten. Yogyakarta, 15\&21 Mei 2008.

Yanto, Supri. 2019. "Pengaruh Workshop Media Pembelajaran Terhadap Peningkatan Kompetensi Guru dalam Mengembangkan Media Pembelajaran Di SMP Negeri 26 Makassar". $\quad$ Skripsi. Teknologi Pendidikan. UNM. Makassar.

Yusuf, Muri. 2017. Metode Penelitian Kuantitatif, Kualitatif dan Penelitian Gabungan. Jakarta: PT. Fajar Interpratama Mandiri. 